\title{
Effect of silica on phospholipids in the rat lung
}

\author{
M. GRÜNSPAN, H. ANTWEILER, and W. DEHNEN
}

Medizinisches Institut für Lufthygiene und Silikoseforschung an der Universität Düsseldorf, Düsseldorf, Gurlittstraße 53, West Germany

Grünspan, M., Antweiler, H., and Dehnen, W. (1973). British Journal of Industrial Medicine, 30, 74-77. Effect of silica on phospholipids in the rat lung. The total amount of phospholipids and the contents of sphingomyelin, phosphatidylcholine, phosphatidylserine, and phosphatidylethanolamine have been estimated in the lungs of rats from 2 to 90 days after intratracheal injections of quartz and corundum, respectively.

A significant increase in the contents of lung total phospholipids and of all phospholipid fractions examined was caused by quartz. The first increase was noted 48 hours after quartz application; after 30 days the amount of phosphatidylcholine had increased to about 20 -fold, whereas the other phospholipid fractions had reached only an amount two or three times as great as in the control animals. The increase observed was steady for up to 90 days at the end of these experiments.

The increase in lung phospholipids was far less when corundum was injected into the lungs.

The increase in lung lipids after quartz dust inhalation has been studied in rabbits and guinea-pigs by Fallon (1937), Marks and Marasas (1960), and Baily, Kilroe-Smith, and Harington (1963). These investigations referred to the total lipid content of the lung. Changes that might occur in the phospholipid fractions are still unknown.

Phosphatidylcholine plays an important role in the composition of the antiatelectatic factor (Pattle, 1965) and phosphatidylserine participates in the phagocytosis mechanism of alveolar macrophages (Karnovsky and Wallach, 1961).

Recently we reported changes in the phospholipid content of the lungs of rats after intratracheal injection of quartz (Grünspan and Antweiler, 1970). In these studies it has been established that quantitative and qualitative changes in lung lipid composition take place during experimental silicosis.

In the present study the total amount and the composition of phospholipids in the lungs of normal and quartz-treated rats were analysed at various intervals from 2 to 90 days after quartz application; corundum served for comparison as a non-fibrogenic inert dust.

\section{Materials and methods}

Adult female wistar rats (Firma Iwanowas), weighing 180 to $200 \mathrm{~g}$, were used for these experiments. They were maintained on a commercial standard diet.

Three groups of animals were injected intratracheally as follows:

(a) $0.5 \mathrm{ml} \mathrm{NaCl} 0.9 \%$ (controls): 60 rats

(b) $20 \mathrm{mg}$ quartz suspended in $0.5 \mathrm{ml} \mathrm{NaCl} \mathrm{0.9 \% :220}$ rats

(c) $20 \mathrm{mg}$ corundum suspended in $0.5 \mathrm{ml} \mathrm{NaCl} 0.9 \%$ : 30 rats.

The maximum particle size of quartz and corundum (Dörentrup No. 12) was $3 \mu \mathrm{m}$. The specific quartz surface amounted to $9 \cdot 1 \mathrm{~m}^{2} / \mathrm{g}$ and that of corundum to $5 \cdot 34 \mathrm{~m}^{2} / \mathrm{g}$.

Preparation of dust suspensions

Quartz or corundum, $1 \mathrm{~g}$, was mixed with $25 \mathrm{ml} 0.9 \%$ 
$\mathrm{NaCl}$. The suspension was gently agitated with a magnetic stirrer and sonicated (MSE $100 \mathrm{~W}$, Ultrasonic disintegrator: $20 \mathrm{~K} \mathrm{c} / \mathrm{s})$. Until it was used the quartz suspension was stored at $37^{\circ} \mathrm{C}$ with stirring.

\section{Intratracheal injection of quartz}

The rats were lightly anaesthetized with ether. A curved cannula was introduced into the trachea through the larynx and the suspensions were rapidly injected.

\section{Preparation of lungs for analysis}

Rats were killed by having their throats cut. After exsanguination, the lungs were removed and dried between pieces of filter paper. The lungs were weighed without trachea, lymph nodes, or fat tissue. Then the lungs from each animal were minced with fine scissors. The lipids were determined in the lungs of each animal separately.

\section{Lipid extraction}

The lipids were extracted by the method of Folch, Lees, and Sloane Stanley (1957): $1 \mathrm{~g}$ of the minced lung was homogenized for 2 minutes in $5 \mathrm{ml}$ chloroform-methanol mixture $(2: 1 \mathrm{v} / \mathrm{v})$ at a speed of $10000 \mathrm{rev} / \mathrm{min}$ (BühlerHomogenizer). Then the chloroform-methanol mixture was added to make a total volume of $20 \mathrm{ml}$.

The upper methanol-water phase was discarded. The lower, predominantly chloroform phase, containing all the lung lipids, was kept at $-20^{\circ} \mathrm{C}$. All subsequent phospholipid analyses were carried out in duplicate on aliquots of this solution.

\section{Determination of phospholipids}

The chloroform extracts were evaporated under a stream of nitrogen to a volume of $5 \mathrm{ml}$. Aliquots of $25 \mu \mathrm{l}$ were spotted on a silica-coated glass plate (Kieselgel H Merck). Thin-layer chromatography was performed according to Brockmann and Gercken (1969).

The following fractions were determined quantitatively based on phosphate analysis: sphingomyelin, phosphatidylchloline, phosphatidylserine, and phosphatidylethanolamine. The lipid fractions, estimated with this method, are of course not necessarily homogeneous. The separated phospholipid fractions were visualized by iodine vapour, scraped off, transferred to glass tubes and heated in an aluminium block for 1 hour and, after addition of $0.2 \mathrm{ml}$ perchloric acid, for a further 1 hour at $180^{\circ} \mathrm{C}$. The clear samples were diluted with $5 \mathrm{ml}$ water and treated with $0.5 \mathrm{ml} 10 \%$ ammonium heptamolybdate and $0.5 \mathrm{ml}$ of a solution containing $0.1 \% 1$-amino-2hydroxynaphthalenesulphonic acid, $0.2 \%$ sodium sulphite, and $0.6 \%$ sodium metabisulphite. The capped glass tubes were heated in a boiling water-bath for 10 minutes, and the blue colour formed was read in a photometer at $830 \mathrm{~nm}$. The phosphate content of each tube was calculated using identically treated standards.

The total content of phospholipids was determined after digestion of an aliquot of the chloroform extract in the manner described above. The results are expressed as micromoles phosphate per lung.

\section{Results}

\section{Lung phospholipids}

Total phospholipids A highly significant progressive increase in the total phospholipid content of the lungs was observed during the development of pulmonary silicosis.

This increase begins 48 hours after the intratracheal injection of quartz and reaches a nearly 14fold higher value than the controls at 30 days and an about 24-fold higher value at 90 days after quartz application. The increase of total phospholipids in the controls and in corundum-treated rats at 30 days after injection is not significant, although at $\mathbf{1 5}$ days there was a clearcut increase in the amount of total phospholipids of nearly $35 \%$ of the starting value (Table 1).

Composition of lung phospholipids In Table 2 the amounts of sphingomyelin, phosphatidylcholine, phosphatidylserine, and phosphatidylethanolamine in the lungs of animals treated with quartz are shown in comparison with the values obtained after injection of corundum or physiological saline (controls).

The normal values of our experiment agree with

TABLE 1

Total Phospholipids ( $\mu \mathrm{mol} / \mathrm{LuNG}$ )

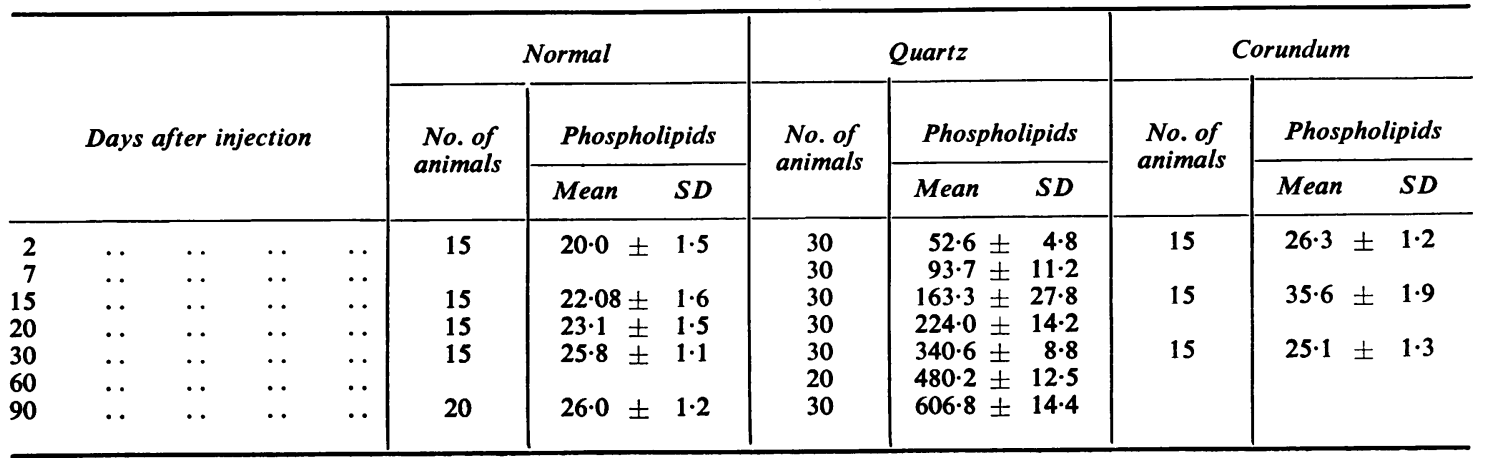


TABLE 2

Changes in Individual Phospholipids ( $\mu$ mol/Lung)

\begin{tabular}{|c|c|c|c|c|c|c|c|c|c|c|c|c|c|c|c|}
\hline \multirow{2}{*}{$\begin{array}{c}\text { Days } \\
\text { after } \\
\text { injection }\end{array}$} & \multicolumn{5}{|c|}{ Normal } & \multicolumn{5}{|c|}{ Quartz } & \multicolumn{5}{|c|}{ Corundum } \\
\hline & $\begin{array}{c}\text { No. of } \\
\text { animals }\end{array}$ & $S M$ & $P C$ & $P S$ & $P E$ & $\begin{array}{c}\text { No. of } \\
\text { animals }\end{array}$ & $S M$ & $P C$ & $P S$ & $P E$ & $\begin{array}{c}\text { No. of } \\
\text { animals }\end{array}$ & $S M$ & $P C$ & $P S$ & $P E \frac{\overline{\bar{\sigma}}}{\bar{\omega}}$ \\
\hline 2 & 15 & $\begin{array}{r}2 \cdot 3 \\
\pm 0.3\end{array}$ & $\begin{array}{r}12.5 \\
\pm 1.5\end{array}$ & $\begin{array}{r}2.1 \\
\pm 0.4\end{array}$ & $\begin{array}{r}5.3 \\
\pm 0.5\end{array}$ & 30 & $\begin{array}{r}3 \cdot 1^{2} \\
\pm 0 \cdot 9 \\
\end{array}$ & $\begin{array}{c}32 \cdot 2^{2} \\
\pm 4 \cdot 3\end{array}$ & $\begin{array}{r}5 \cdot 2^{1} \\
\pm 0 \cdot 8 \\
\end{array}$ & $\begin{array}{c}12 \cdot 4^{1} \\
\pm 1 \cdot 5 \\
\end{array}$ & & & & & $\frac{2}{0}$ \\
\hline 7 & 15 & $\begin{array}{r}2.6 \\
\pm 0.3\end{array}$ & $\begin{array}{r}14 \cdot 5 \\
\pm 1 \cdot 3\end{array}$ & $\begin{array}{r}2.3 \\
\pm 0.4\end{array}$ & $\begin{array}{r}5 \cdot 1 \\
\pm 0.4\end{array}$ & $\begin{array}{l}30 \\
30\end{array}$ & $\begin{array}{r}5.4^{1} \\
\pm 0.7 \\
\end{array}$ & $\begin{array}{r}63 \cdot 3^{1} \\
\pm 10 \cdot 8 \\
\end{array}$ & $\begin{array}{r}9 \cdot 6^{1} \\
\pm 0.9 \\
\end{array}$ & $\begin{array}{c}15 \cdot 3^{1} \\
\pm 1 \cdot 9\end{array}$ & & & & & \\
\hline $14 / 15$ & & & & & & 30 & $\begin{array}{r}7 \cdot 5^{1} \\
\pm 1 \cdot 7\end{array}$ & $\begin{array}{r}127 \cdot 8 \\
\pm 27 \cdot 5\end{array}$ & $\begin{array}{r}8.9^{1} \\
\pm 1.5\end{array}$ & $\begin{array}{c}19 \cdot 1^{1} \\
\pm 4 \cdot 0\end{array}$ & 15 & $\begin{array}{r}3 \cdot 5^{1} \\
\pm 0.4 \\
\end{array}$ & $\begin{array}{l}24 \cdot 8^{1} \\
\pm 1 \cdot 5 \\
\end{array}$ & $\begin{array}{r}2 \cdot 1 \\
\pm 0 \cdot 2 \\
\end{array}$ & $\begin{array}{r}5.2 \omega \\
\pm 0.5 \mathrm{O} \\
\end{array}$ \\
\hline $20 / 21$ & 15 & $\begin{array}{r}2 \cdot 8 \\
\pm 0 \cdot 3\end{array}$ & $\begin{array}{r}13 \cdot 6 \\
\pm 1 \cdot 2\end{array}$ & $\begin{array}{r}2.4 \\
\pm 0.4\end{array}$ & & 30 & $\begin{array}{r}4 \cdot 5^{1} \\
\pm 0 \cdot 6\end{array}$ & $\begin{array}{r}192.0^{1} \\
\pm 13.4\end{array}$ & $\begin{array}{r}7 \cdot 3^{1} \\
\pm 0 \cdot 6\end{array}$ & $\begin{array}{c}19 \cdot 4^{1} \\
\pm 4 \cdot 6\end{array}$ & & & & & \\
\hline 30 & 15 & $\begin{array}{r}2 \cdot 2 \\
\pm 0.4\end{array}$ & $\begin{array}{r}11 \cdot 1 \\
\pm 1 \cdot 4\end{array}$ & $\begin{array}{r}1 \cdot 2 \\
\pm 0.4\end{array}$ & $\begin{array}{r}3.0 \\
\pm 0.4\end{array}$ & 30 & $\begin{array}{r}5 \cdot 8^{1} \\
\pm 0.6\end{array}$ & $\begin{array}{l}299 \cdot 7^{1} \\
\pm 8 \cdot 7\end{array}$ & $\begin{array}{c}15 \cdot 1^{1} \\
\pm 0 \cdot 8\end{array}$ & $\begin{array}{c}19 \cdot 6^{1} \\
\pm 0 \cdot 7\end{array}$ & 15 & $\begin{array}{r}2.2 \\
\pm 0.3\end{array}$ & $\begin{array}{c}16 \cdot 6^{2} \\
\pm 1 \cdot 2\end{array}$ & $\begin{array}{r}1 \cdot 3 \\
\pm 0.3\end{array}$ & $\begin{array}{r}4.8 \overrightarrow{2} \\
\pm 0.3 \overrightarrow{+} \\
\text { 은 }\end{array}$ \\
\hline
\end{tabular}

For normal rats compared to quartz or corundum rats: ${ }^{1}$ means $\mathbf{P}<0.01 \quad{ }^{2}$ means $\mathbf{P}<0.05$

$\mathbf{S M}=$ sphingomyelin; $\mathbf{P C}=$ phosphatidylcholine; $\mathrm{PS}=$ phosphatidylserine; $\mathrm{PE}=$ phosphatidylethanolamine

the results of other analyses of the lipids of rat lungs (Fletcher and Wyatt, 1970). The main component of the rat lung phospholipids is phosphatidylcholine.

In the control animals there is an insignificant increase in the composition of lung phospholipids. In corundum animals a significant increase was seen only in some values, mainly in phosphatidylcholine at 15 days after corundum injection.

In all the animals an increase in all the four fractions can be recognized 48 hours after the intratracheal injection of quartz. This is due to an increase of all the phospholipid components and mainly to phosphatidylcholine.

The animals were observed for 90 days and it was found that a phospholipid increase accompanied the development of silicosis in all rats which were injected intratracheally with quartz.

In the corundum-treated rats such a high increase was never observed.

\section{Discussion}

As can be seen from Table 3, the percentage distribution of phospholipid fractions in the normal rat closely resembles the distribution in human lungs (Wichert, 1971). This fact and the close resemblance of the human silicotic nodule to that produced experimentally in rats (Belt, Ferris, and King, 1940) indicate that the rat is a good model in which to study the changes in phospholipid composition during the development of pulmonary silicosis.

The investigation by Kaw, Gupta, and Zaidi 1971) concerns total phospholipids; the first estima-
TABLE 3

Phospholipids in Human Lungs and Rat Lungs

\begin{tabular}{ll|c|c|c|c}
\hline \multirow{1}{*}{ Lungs } & & \multicolumn{4}{|c}{$\begin{array}{c}\% \\
\text { Relative distribution } \\
\text { (average values) }\end{array}$} \\
\cline { 2 - 5 } & & $S M$ & $P C$ & $P S$ & $P E$ \\
\hline $\begin{array}{l}\text { Human } \\
\text { (Wichert, 1971) }\end{array}$ & $\ldots$ & 14.5 & 47.0 & 7.9 & 22.5 \\
$\begin{array}{l}\text { Rat } \\
\text { (This study) }\end{array}$ & $\ldots$ & 8.6 & 48.2 & 7.4 & 17.8 \\
\hline
\end{tabular}

tions were made 50 days after the intratracheal injection of quartz. No values are given for the composition of lung phospholipids.

The quantitative estimation of the phospholipid composition during the development of silicosis in rats is a problem which has been studied recently by Grünspan and Antweiler (1970).

The results reported here on rats are similar to those described by Baily et al. (1963) and Marks and Marasas (1960) on guinea-pigs after intratracheal injection of quartz. The increase of total phospholipids is caused not only by the increase of phosphatidylcholine but of all the fractions of phospholipids which have been estimated, based on phosphate analysis.

The first increase was noted 48 hours after the intratracheal injection of quartz. This phenomenon 
shows the very early appearance of the phospholipid changes caused by quartz. During the development of experimental silicosis the amount of sphingomyelin, phosphatidylserine, and phosphatidylethanolamine increased only two or three times, while the amount of phosphatidylcholine increased about 20 -fold. A far less significant increase in phospholipid content is produced by corundum.

Phosphatidylcholine is the major component of the antiatelectatic factor (surfactant) in the lungs from all animal species examined (adult frog, turtle, chicken, rat, sea lion, dog, mouse, rabbit, guineapig (Clements, 1971)). The phospholipids estimated by us in the total lungs are obtained from the cellular tissue and the alveolar surface. The increase in lung phospholipids caused by quartz could be due not only to the production of intracellular phospholipids but also to extracellular phospholipids (surfactant).

No increase in total phospholipids or phosphatidylcholine content was noted during acute inflammation in human lungs; on the contrary, a decrease in total phospholipids, particularly phosphatidylcholine, was found (Wichert, 1971). Also, no increase was seen in the phospholipid content and composition of rat lung after poisoning with paraquat (1.1'-dimethyl-4'-dipiridilium) (Fletcher and Wyatt, 1970), although the lung was infiltrated by large numbers of macrophages (Clark, McElligott, and Weston Hurst, 1966). A consequence of paraquat poisoning in rats is rather a decrease in the amount of the phospholipid of pulmonary surfactant (Pattle, 1965).

Hence necrosis of pulmonary tissue or macrophages is probably not responsible for the increase in phospholipid content of the lungs of quartztreated animals. The phospholipid and especially the phosphatidylcholine increase in quartz lung seems to be a typical biochemical reaction caused by quartz. The mechanism of these changes in lung lipids is unknown. We believe that it is a primary phenomenon inasmuch as the quartz probably causes an impairment between production and destruction of the phospholipids in the lungs. This impairment is clearly reversed by polyvinylpyridine-
$\mathrm{N}$-oxide, as has been observed recently (unpublished results). Further investigation should clarify the mechanism of changes in the phospholipid content caused by quartz as well as the fatty acid composition of the phospholipids and sphingolipids.

\section{References}

Baily, P., Kilroe-Smith, T. A., and Harington, J. S. (1963). Some lipid constituents of normal and quartz-dusted guinea-pig lungs. Nature, 198, 856-857.

Belt, T. H., Ferris, A. A., and King, E. J. (1940). The silicotic nodule in human and experimental silicosis. Journal of Pathology and Bacteriology, 51, 233-267.

Brockmann, U., and Gercken, G. (1969). Quantitative eindimensionale Dunnschichtchromatographie der Erythrozytenphospholipide. Clinica Chimica Acta, 23, 489494.

Clark, D. G., McElligott, T. F., and Weston Hurst, E. (1966). The toxicity of paraquat. British Journal of Industrial Medicine, 23, 126-132.

Clements, J. A. (1971). Comparative lipid chemistry of lungs. Archives of Internal Medicine, 127, 387-389.

Fallon, J. T. (1937). Specific tissue reaction to phospholipids. Canadian Medical Association Journal, 36, 223-228.

Fletcher, K., and Wyatt, I. (1970). The composition of lung lipids after poisoning with paraquat. British Journal of Experimental Pathology, 51, 604-610.

Folch, J., Lees, M., and Sloane Stanley, G. H. (1957). A simple method for the isolation and purification of total lipides from animal tissues. Journal of Biological Chemistry, 226, 497-509.

Grünspan, M., and Antweiler, H. (1970). Biochemical and biophysical reactions of rat lung tissue to quartz and corundum with and without PVPN-oxide treatment. Inhaled Particles III, edited by W. H. Walton, vol. 1, p. 373. Unwin Brothers, Old Woking, Surrey.

Karnovsky, M. L., and Wallach, D. F. H. (1961). The metatolic basis of phagocytosis. Journal of Biological Chemistry, 236, 1895-1901.

Kaw, J. L., Gupta, G. S. D., and Zaidi, S. H. (1971). Lung lipids and pulmonary silicosis in rats. Internationales Archiv für Arbeitsmedizin, 27, 324-330.

Marks, G. S., and Marasas, L. W. (1960). Changes in the lung lipids of rabbits and guinea-pigs exposed to the inhalation of silica dust. British Journal of Industrial Medicine, 17, 31-36.

Pattle, R. E. (1965). Surface lining of lung alveoli. Physiological Reviews, 45, 48-79.

Wichert, P. von (1971). Beziehungen zwischen pathologischen Veränderungen und Phospholipidgehalt der menschlichen Lunge. Pneumologie, 144, 201-205.

Received for publication December 12, 1971. 